\title{
AMBIGUITIES IN THE CHANDLER ACT *
}

\section{JoHN E. MULDER $\dagger$}

The statement that legislation can be "scientifically" created seems a platitude. But it is a platitude too frequently disregarded. ${ }^{1}$ One may object to the use of the word "scientific" in this connection, but it will suffice for the want of a better. The fact remains, however, that great masses of laws are poorly conceived and atrociously drafted, resulting in confusion and unnecessary litigation. ${ }^{2}$

In the broad field of commercial law "scientific" legislation is especially possible and especially important. For here there can be calm, dispassionate judgment, removed from the fervor and pull of politics. Such deliberation seems essential in matters which affect the pocketbook of the man in the street. In commercial law, when evils are prevalent, it is possible to ascertain the facts surrounding the evils as a basis for reform. It is possible to secure the aid of experts familiar with relevant case law and awake to judicial attitudes. ${ }^{8}$ Such truths, almost too obvious for mention, are nonetheless too frequently ignored. Now, with such preliminary information at hand, all points of view and all interests would be represented by the collaboration of lawyers, professors, economists and businessmen. ${ }^{4}$ Such a group would formulate objectives and statements of purpose, which should be generally available after enactment, as a guide to administration and interpretation. After enactment, a law and its administration should be carefully and constantly scrutinized with a view to amendment when the need should arise.

Legislation so conceived may well be labelled "scientific". It should produce improvement where improvement is needed. Soundly conceived and skillfully drafted, it should inevitably reduce the quantum of litigation. And such a task is not too difficult.

There is cause for enthusiasm in the discovery that the Chandler Act is one of the most "scientifically" created pieces of legislation ever

* The substance of this paper was delivered at the Annual Conference of the Judges of the Third Judicial Circuit in Atlantic City, New Jersey, on September 27, 1940.

$\dagger$ A. B., I928, State University of Iowa; LL. B., I93I, University of Wisconsin; LL. M., I932, Columbia University; Associate Professor of Law, University of Pennsylvania; Co-Editor, ColsIER ON BANKRUPTCY (I4th ed.); Editor-in-Chief, BIII, OF RIGHTS REvIEw; author of Effect of the Chandler Act Upon General Assignments and Compositions (I939) 87 U. OF PA. L. REv. 763, and other articles in various legal periodicals.

I. See Cardozo, A Ministry of Justice (Igar) 35 HaRv. L. REv. II3; Landis, The Implications of Modern Legislation to Law Teaching (I934) HANDEOOK of THE Ass'N. of AMERICAN LAw Schools 122; Mulder, Some Obstacles to Effective Legislation. (I936) 3 I ILL. L. REv. 24.

2. See examples cited in Mulder, note I supra at 29.

3. Cardozo, note I supra; Mulder, note I supra at 33 et seq.

4. Cardozo, note I supra at I24. 
penned by the hand of man. The need for drastic revision of the Bankruptcy Act of 1898 had long been apparent. ${ }^{5}$ Economic conditions had brought awareness that the Act was now creaking with antiquity. It needed more than a new coat of paint. A modern, streamlined version was essential. Further, the fact material was at handan official report, based upon a painstaking, unbiased study of the Act of $x 898$, which painted a sordid picture of inefficiency, dishonesty, and inadequacy of administration. ${ }^{8}$ An unselfish group of men, all experts, from various fields of activity, representing all points of view, joined hands in the arduous task of reformation. ${ }^{7}$ Among them were scholars well-versed in the great body of case law which had developed under the Act of $18 \mathrm{~g} 8$. They held numerous public hearings as their work progressed in conjunction with the appropriate Congressional Committees. They set up a list of ten major objectives to be attained under the new Act. Those objectives, now publicly available, constitute an ever-present help to one in retaining perspective when confronted with specific problems. ${ }^{8}$ In addition, the more specific intent of the framers with reference to particular sections of the Act are in published form. ${ }^{9}$ In one instance there may have been the purpose to incorporate or overrule a pertinent decision of the United States Supreme Court; ${ }^{10}$ in

5. Billig, What Price Bankruptcy: A Plea for "Friendly Adjustment" (I929) I4 Corn. L. Q. 413 at 444; Donovan, A Report on the AdMinistration OF BanKRUPTCY ESTATES (I930).

6. Donovan, note 5 supra. See Billig, note 5 supra at $4 \mathrm{I} 3,4 \mathrm{I} 4$

7. "The Chandler Act is the result of six years of earnest and intensive work on the part of the bankruptcy committees of the American Bar Association, the Commercial Law League of America, the National Association of Bankruptcy Referees, the $\mathrm{Na}$ tional Association of Credit Men, the American Bankers Association, law-school professors, authors of texts on bankruptcy, and others, comprising the National Bankruptcy Conference. The members of this Conference, experts in their respective fields, have devoted themselves to a comprehensive study of economic and business conditions and to the building up of a revised bankruptcy law that would best serve the requirements and interests of both debtors and creditors. In so doing, they have been careful to preserve such parts of the prior law as have been proved by long experience to be workable and satisfactory. But they have been equally careful to discard what had become useless or inadequate and to modify and supply procedure which is adapted not only to the demands of existing conditions but which is sufficiently flexible to meet changing conditions.

"The Chandler Act reflects not alone the views of the National Bankruptcy Conference but also the experience and thought of bar associations, credit organizations and individuals, both professional and lay, to whom a series of drafts were submitted for study and criticism. The hearings before the House and Senate Judiciary Committees, which extended over a period of two years, were participated in by persons representing many views from all sections of the country." WEINSTers, THE BANKRUPTCY LAW OF I938, iv; I COLlIER, BANKRUPTCY (I4th ed. 1940) 20.

8. I Collier, BANKRUPTCY (I4th ed. I940) 22.

9. Hanna and Mclaughlin, The Bankruptcy Act of i898 as Amended InCLUDING THe CHANDLER ACT OF I938 (1938); WeINSTEIN, loc. cit. supra note 7.

I0. $\$ 67$ (d) (3) was inserted in an attempt to incorporate the rule of Dear $v$. Davis into our bankruptcy laws. HANNA AND MCLAUGHLIN, op. cit. sipra note 9 at 74. As to whether it has succeeded or not, see infra p. 27.

$\S 60(a)$, by defining the time at which a transfer shall be deemed to have been made, was intended to overrule Martin v. Commercial National Bank, 245 U. S. 5I3 (I918) ; Carey v. Donohue, 240 U. S. 430 (1916) ; Bailey v. Baker Ice Machine Co., 239 U. S. 268 (1915). See HaNna AND MCLaughis, op. cit. supra note 9 at 58. 
another section there may have been an intent to obliterate a previously prevalent evil.11 Obviously these statements of purpose will not provide a panacea for all problems, but the fact remains that now as never before there is available information concerning legislative intent to serve as a guide in ascertaining what was meant by the words employed. Thus ambiguities may be lessened, clarity obtained, and litigation diminished, if such background material is constantly consulted. ${ }^{12}$

The Chandler Act has only recently passed its second birthday. Encouraging evidence of the continuation of the "scientific" attitude is apparent. The National Association of Credit Men, one of the sponsors of the Act, is already conducting a survey of its administration. The Association has circulated among its membership questionnaires designed to discover the extent to which the Act is succeeding or failing in the attainment of its ten major objectives. ${ }^{13}$ A special committee on Bankruptcy Administration, appointed by the Attorney General of the United States, is conducting, through the various law schools of the country, a study of the cases arising under the Chandler Act, with a similar purpose in view. ${ }^{14}$ These surveys are undoubtedly premature. The material available at this early date is insufficient to produce comprehensive analysis. ${ }^{15}$ The sweeping reforms of the Act have not yet been sufficiently absorbed by the Bench and Bar. But the effort is laudable. The cases constitute valuable source material; when a substantial number have been carried through to completion they will form the basis for amendments, correcting mistakes and removing ambiguities. At least, however, the "scientific" attitude is being conscientiously continued.

Current comment on the Chandler Act is favorable. Little disposition to make radical changes is apparent. There seems to be a

II. $\$ I_{4}$ (b) was inserted to allow the trustee greater rights to participate in the proceedings, permitting him to object to a discharge without first obtaining the consent of the creditors. The Act of 1898 , as amended in 1903 , required the consent of the creditors before the trustee could act in such instances. See I CollIER, BANKRUPTCY (14th ed. 1940) 1269.

$\S 57$ (n) brought about two significant changes. It changed the six-month period for proof of claims from time of adjudication to the present requirement of six months from the time of the creditor's first meeting. Secondly, it placed the sovereigns in the same category as other creditors by binding them to the six-month rule. WEINSTEIN, op. cit. supra note 7 at 110 .

12. Compare the judicial fluctuations under the Act of 1898 , Note (1925) 34 YaLE L. J. 89 I.

13. (1940) I4 J. N. A. ReF. BANkr. Ioo.

I4. Discussed in address by Mr. J. I. Weinstein before the Commercial Law Section of the American Bar Association, September Ir, 1940, Proposals of the Attormey General's Committee. See infra p. 33 .

15. Most of the cases carried to completion were uncontested and no-asset cases. Between September 22, 1938, when the Chandler Act went into effect, and March 8, 1940, one hundred and thirty-seven voluntary and seventeen involuntary cases were closed in the Eastern District of Pennsylvania. Most of the voluntary cases were noasset cases and involved few contests productive of information regarding the reforms of the Chandler Act. 
general feeling that better results are already being achieved, that it is better not to tamper until the full import of the reforms have been absorbed and given a fair trial. ${ }^{16}$ But no matter how scientifically conceived, legislation must be constantly altered to meet the exigencies of new situations, exigencies which could not have been anticipated by its makers. Man's limitations are ever made manifest when his handiwork is submitted to the practical test. And new situations arise with such rapid frequency in times of economic unbalance that defects in the Act have already cropped up. Mistakes in draftsmanship have become apparent; some difficulties were not anticipated; omissions have come to light; and phraseology is at times needlessly ambiguous. It is not amiss to place these revelations on the table where they can be microscopically examined and evaluated.

Attention will be directed in this paper to various instances of faulty draftsmanship which have now come to light, to be rectified by the courts as pertinent problems arise, or to be placed eventually in the hands of Congress for amendment. The symposium on Bankruptcy at the recent American Bar Association Convention dealt with the more popular and better-known aspects of the Act. ${ }^{17}$ Consideration will here be devoted mainly to an examination of the less-talked of problems which, though important, may otherwise remain unnoticed.

Until very recently bankruptcy meant liquidation of a debtor's assets and distribution of the proceeds among the creditors. The Act of 1898 concerned itself almost completely with that aspect of bankruptcy, devoting thereto approximately seventy-two sections. ${ }^{18}$ The liquidation machinery is retained in the Chandler Act, but weak spots which had long gone unnoticed have been repaired; ${ }^{19}$ serious efforts have been made to curb dishonest bankruptcies; ${ }^{20}$ clarity of expression far.

16. Few amendments dealing with matters of substance have been proposed thus

17. The addresses included the following: Robert T. Swaine, Railroad Reorganizations and Legislative Proposals Affecting Them; Randolph E. Paul, Tax Problems in Reorganizations; W. Randolph Montgomery, Chapter XI of the Bankruptcy Act: Should It Be Drastically Revised?

I8. Until 1933, only $\$$ I2 dealt with rehabilitation, by means of a bankruptcy composition.

I9. $\$ \$ 70$ (a) (7) dealing with various types of future interests held by the bankrupt in realty, and 70 (a) (8) dealing with property passing to the bankrupt by devise, bequest, or inheritance within a period of six months after bankruptcy, are now present to promote a greater realization of assets, assets which were formerly outside of the sphere of the bankruptcy courts. See HaNNa AND MCLAUghlin, op. cit. supra note 9 at 78; WEINSTEIN, op. cit. supra note 7 at I58, I59.

$\$ 60$ of the Act has more definitely stated the time limit of transfers and has, therefore, done away with secret transfers to a large extent. This feature is discussed at greater length, infra at p. 22 .

Another section which underwent a great change for the better is $\S 67$, also discussed infra at p. 26.

20. Wolfe, Detection of Fraud Under the New Banknuptcy Law (1938) 13 Tear. L. Q. I. See infra p. 34 . 
and uniformity of terminology have been attempted; ${ }^{21}$ and procedural provisions have been altered in the interests of speed and efficiency. ${ }^{22}$ The remainder of the Act represents something new in bankruptcy legislation. It proceeds not upon a concept of liquidation but rather upon a theory of rehabilitation of unfortunate debtors. The economic depression created the need for rehabilitation, and, commencing in ${ }^{1933,}{ }^{23}$ the need found expression in piecemeal amendments to the Bankruptcy Act. Rehabilitation becomes an established feature in the Chandler Act, in the forms of Arrangements, Real Property Arrangements, Wage Earners' Adjustments, Agricultural Adjustments, Railroad Reorganizations, Corporate Reorganizations and Municipal Debt Plans. ${ }^{24}$

Recent events tend to vindicate the foresight of the fathers of the Chandler Act. The rehabilitation provisions have assumed preeminence in bankruptcy administration. Perhaps this manifests a permanent trend toward the use of rehabilitation where possible, with resort to liquidation or straight bankruptcy only when rehabilitation becomes impracticable. ${ }^{25}$ Or it may be merely the result of presentday economic conditions, or the popularity that usually attends something novel and new. At any rate, non-asset cases now seem to predominate in straight bankruptcy. ${ }^{26}$. However, probably one hundred million individuals, as well as thousands of partnerships and corporations, remain eligible for straight bankruptcy, which cannot as yet be considered a dead letter in the law. It should also be remembered that important sections contained in the liquidation portions of the Act, probably because they have always been there, are applicable as well to proceedings for rehabilitation. ${ }^{27}$ Hence, they remain of significance.

The liquidation provisions of the Act are based upon approximately forty years of experience, accompanied by a vast accumulated

2I. By way of illustration note the identity of phraseology in $\S \S 3$ (b), 60 (a), and 67 (d) (5), dealing with the time at which a transfer becomes perfected.

22. Wolfe, note 20 supra. See infra p. 33.

23. The Act of 1933, added Chapter VIII, containing $\$ \$ 73,74,75,76$ and 77 to the bankruptcy laws. In I934, $\$ 79$ and 80 , dealing with municipal debt readjustments were added. [These two sections were invalidated as unconstitutional in Ashton v. Cameron Co., 298 U. S. 513 (1936).] The last amendments, by the Act of 1934, added $\S 77$ (a) and $\$ 77$ (b) to the Act.

For a brief summary of the post-depression changes see I COLLIER, BANKRUPTCY (14th ed. I940) 14 .

24. Chapter XI, Chapter XII, Chapter XIII, \& 75 (s), §77, Chapter X, Chapter IX, respectively.

25. As a practical matter, rehabilitation should have great permanent utility. In straight bankruptcy, a debtor having liabilities in excess of assets is usually beyond hope; but in rehabilitation proceedings he may be potentially solvent, but merely unable to meet his debts as they mature.

26. See note 15 suprc.

27. See $\$ \S 102,302,402,602$. 
body of case law. ${ }^{28}$ The rehabilitation portions are frankly experimental in nature. Consequently, no surprise is occasioned by the fact that greater difficulties and more frequent ambiguities are being encountered in the rehabilitation features.

\section{Arrangements Under Chapter XI}

It was the hope of the draftsmen that Chapter XI would repopularize the bankruptcy composition. That hope has been realized with dramatic suddenness. In fact, there has been a veritable stampede of petitions under this chapter. Because of the unanticipated character of many of these petitions, vulnerable weak spots have immediately come to the forefront, giving rise to numerous judicial difficulties.

The bankruptcy composition in itself is nothing new. Provision therefor had existed since 1898 in Section I2. Thereunder a bankrupt could attempt rehabilitation by securing the consent of his creditors to pay them off on a pro rata or instalment basis. In a common-law com. position, only assenting creditors were bound; non-assenters received no share in the proceeds, but retained their claims against the debtor in toto. ${ }^{29}$ To a debtor, the desirable feature of a composition under Section 12 was that non-assenting creditors were also bound, provided a majority of the total number approved, and the court found the plan to be in the best interests of creditors. ${ }^{30}$ The subsequent discharge released the bankrupt from all of the unsecured provable claims against him. ${ }^{81}$

In theory, Section 12 offered a quick, simple and economic means of rehabilitation to an unfortunate debtor and the promise of greater dividends to creditors than would be forthcoming in straight bankruptcy. In practice, however, such was not the case. Since the debtor was already a bankrupt, he was too frequently beyond financial rehabilitation. ${ }^{32}$ The machinery proved cumbersome and expensive, and Section 12 , throughout its existence, remained substantially a dead letter. In I933 Section 74, which sought to eliminate the difficulties of Section I2, was adopted in order to repopularize the bankruptcy com-

28. The American Bankruptcy Reports, commencing at the time of adoption of the Act of $I 898$, now comprise more than ninety volumes.

29. GLen,, Ligumation (1935) $\$ \$ 84$-I04; Mulder and Solomon, Effect of the Chandler Act Upon General Assignments and Compositions (I939) 87 U. OF PA. L. REv. 763 .

30. J. B. Weinstein, The Debtor Relief Chapters of the Chandler Act (r938) 5 U. of PITT. L. Rev. I, I4. See also In re Speller, 230 Fed. 490 (D. Mass. I9I6). (I927).

3r. Bankruptcy Act of I $898, \S$ I4 (c), 30 STAT. 550 (I\&98), II U. S. C. A. § 32 (c)

32. § I2 read: "A bankrupt may offer terms of composition. . . ." See WEINSTEIN, op. cit. supra note 7 at 260 ; Mulder and Solomon, note 29 supra at 787 ; Weinstein, note 30 supra at 14 . 
position. But Section 74 in turn gave rise to so many difficulties that failure again followed. ${ }^{33}$

Chapter XI now replaces Sections 12 and 74 and is supposed to have simplified and speeded up the composition machinery. It provides in brief that a debtor, whether an individual or a corporation, may work out a simple arrangement with his unsecured creditors, by which he can remain in business and retain the goodwill of his going concern. ${ }^{34} \mathrm{He}$ secures the consent of his creditors to scale down his debts or to extend the time of their payment. Insofar as corporations were concerned, Chapter XI seemed, from its inception, to be doomed to failure, for usually financial difficulties of a corporation result from inability to meet payments on secured debts. This at once excludes the enterprise from Chapter XI, which is concerned only with unsecured debts. ${ }^{35}$ Obviously the Chapter is suited for use only by individuals and small corporations having no secured indebtedness, or for business enterprises which are not desirous of modifying their secured indebtedness. It is therefore undoubtedly to the surprise of the draftsmen that courts have been literally flooded with petitions by large corporations seeking to adjust their difficulties under Chapter XI rather than Chapter $X$. The reason for this has now become apparent.

Chapter X, which replaces Section $77 B$, contains intricate and detailed provisions for corporate reorganizations. ${ }^{38}$ Proceedings thereunder are prone to be drawn out and expensive. Usually the appointment of a disinterested trustee is mandatory. ${ }^{37}$ The trustee originates

33. WEINSTEIN, op. cit. supra note 7 at 260 ; Mulder and Solomon, note 29 supra at 788; Weinstein, note 30 supra at 16.

34. WEINSTEIN, op. cit. supra note 7 at 260-261; Mulder and Solomon, note 29 supra at 788-789.

35. $\$ 307$ (I). "An arrangement within the meaning of this chapter shall include provisions modifying or altering the rights of unsecured creditors generally or some class of them, upon any terms or for any consideration." (Italics supplied.) Moore's BANKRUPTCY MANUAL (I939) 648; WeINStern, op. cit. supra note 7 at 264; Weinstein, note 30 supra at $16-17$.

36. For a discussion of Chapter $\mathrm{X}$ see: Gerdes, Corporate Reorganizations: Changes Effected by Chapter $X$ of the Bankmiptcy Act (1938) 52 HARv. L. REv. I; Gerdes, Corporate Reorganizations (1939) 13 J. N. A. REF. BANkR. 67; Graham, Fair Reorganization Plans Under Chapter $X$ of the Chasdler Act (I938) 8 BROokLYN L. REv. 137; Heuston, Corporate Reorganizations Under the Chandler Act (I938) 38 CoL. L. REv. II99; Levi and Moore, Bankruptcy and Reorganization: $A$ Survey of Changes (1938) 5 U. OF CHI. L. REv. 398; Rostow and Cutler, Competing Systems of Corporate Reorganization: Chapters $X$ and XI of the Bankruptcy Act (1939) 48 YALE L. J. I334; Rosenberg, Reorganizations Yesterday, Today, Tomorrow (1938) 25 VA. L. REv. I29; Teton, Reorganization Revised (1939) 48 Y ALE L. J. 573.

37. "Upon the approval of a petition, the judge shall, if the indebtedness of a debtor, liquidated as to amount and not contingent as to liability, is $\$ 250,000$ or over, appoint one or more trustees. Any trustee appointed under this chapter shall be disinterested and shall have the qualifications prescribed in Section 45 of this Act, except that the trustee need not reside or have his office within the district. If such indebtedness is less than $\$ 250,000$, the judge may appoint one or more such trustees or he may continue the debtor in possession. In any case where a trustee is appointed the judge may, for the purposes specified in Section 189 of this Act, appoint as an additional trustee a person who is a director, officer, or employee of the debtor." \$ 156 . See Israels, Some Problems of Policy and Procedure in the Conduct of Reorganization Proceedings (I940) 89 U. OF PA. L. REv. 63. 
and controls the reorganization plan. ${ }^{38}$ Usually the Securities and Exchange Commission will participate generally in the proceedings and will pass upon the fairness or unfairness of a plan. ${ }^{39}$ In theory, at least, the creditors have no say with respect to the plan until the tail end of the proceedings. ${ }^{40}$ Acceptances obtained by them prior thereto are invalid. ${ }^{41}$ The powerful creditors' committees, the control of reorganizations by management and creditors' groups are, more than in mere theory, a thing of the past. ${ }^{42}$ It is this reversal of process, this court control, and this power of the Securities and Exchange Commission which persuades corporations to avoid Chapter $X$. Instead they seek a haven under Chapter XI. For Chapter XI makes no mention of participation by the Securities and Exchange Commission. Acceptances to the plan obtained even prior to commencement of the proceedings may be valid. ${ }^{43}$ The appointment of a trustee is not mandatory, ${ }^{44}$ and the machinery, at least on the surface, is speedy and inexpensive.

38. "Where a trustee has been appointed the judge shall fix a time within which the trustee shall prepare and file a plan, or a report of his reasons why a plan cannot be effected, and shall fix a subsequent time for a hearing on such plan or report and for the consideration of any objections which may be made or of such amendments or plans as may be proposed by the debtor or by any creditor or stockholder." \$ I69. WEINSTEIN, $o p$. cit. supra note 7 at 217 ; Heuston, supra note 36 at 1215.

39. "The Securities and Exchange Commission shall, if requested by the judge, and may, upon its own motion if approved by the judge, file a notice of its appearance in a proceeding under this chapter. Upon the filing of such a notice, the Commission shall be deemed to be a party in interest, with the right to be heard on all matters arising in such proceeding, and shall be deemed to have intervened in respect of all matters in such proceeding with the same force and effect as if a petition for that purpose had been allowed by the judge; but the Commission may not appeal or file any petition for appeal in any such proceeding." \$208. See also § I72. WEINSTEIN, op. cit. supra note 7 at 230.

40. "After the hearing, as provided in Section 169 or Section 170 of this Act, and, if a plan has been submitted to the Securities and Exchange Commission, as provided in Section 172 of this Act, then after filing of the report or notice that it will not be filed, or after the expiration of the time for its filing, whichever first occurs, the judge shall enter an order approving the plan or plans which in his opinion comply with the provisions of Section 216 of this Act, and which are fair and equitable, and feasible, and shall fix a time within which the creditors and stockholders affected thereby may accept the same." \$ I74 See Israels, note 37 supra.

4I. "No person shall, without the consent of the court, solicit any acceptance, conditional or unconditional, of any plan, or any authority, conditional or unconditional, to accept any plan, whether by proxy, deposit, power of attorney or otherwise, until after the entry of an order approving such plan and the transmittal thereof to the creditors and stockholders, as provided in Section 175 of this Act; and any such authority or acceptance given, procured, or received by reason of a solicitation prior to such approval and transmittal shall be invalid, unless such consent of the court has been so obtained." \$176.

42. Levi, Corporate Reorganizations and a Ministry of Justice (I938) 23 MINN. L. REV. 3, I2.

43. "At such meeting, or at any adjournment thereof, the judge or referee . . . (4) shall receive and determine the written acceptances of creditors on the proposed arrangement, which acceptances may be obtained by the debtor before or after the filing of a petition under this chapter." $\$ 336$.

44. "The court may, upon the application of any party in interest, appoint, if necessary, a receiver of the property of the debtor, or, if a trustee in bankruptcy has previously been appointed, shall continue such trustee in possession." (Italics added) $\$ 332$. See also $\$ 342$. 
Undoubtedly, Chapter XI is early on the "must" list for amendment. Its manifold ambiguities are undoubtedly caused by the fact that the framers were groping in an experimental field. ${ }^{45}$ They have been accentuated by the unanticipated influx of petitions by large corporations. Recently, however, the Supreme Court, in the United States Realty Corporation case, ${ }^{46}$ has been called upon to settle a few of the problems. In that case a corporation with some seven thousand shares of stock in the hands of the public, and an indebtedness in excess of five million dollars, sought to effectuate an arrangement under Chapter XI. ${ }^{47}$ The Securities and Exchange Commission attempted intervention, asking that the debtor's petition be dismissed upon the ground that the proceedings should have been filed under Chapter $\mathrm{X}$. The ambiguities of the chapter are made more apparent by the fact that the Circuit Court of Appeals, with a dissenting opinion, reversed the District Court, ${ }^{48}$ and by the fact that the Supreme Court split by a six to three vote. The majority opinion is by Mr. Justice Stone and the dissent by Mr. Justice Roberts. Together they present an illuminating discussion of the vague line of demarcation between Chapters $\mathrm{X}$ and XI.

With large corporations, having securities outstanding in the hands of the public, seeking to utilize Chapter XI, it is not surprising that the Securities and Exchange Commission should seek to intervene. The majority of the court, relying upon the broad equitable powers of the bankruptcy court and upon the new Federal Rules of Procedure, ${ }^{49}$ held that the Commission might properly intervene in the public interest. ${ }^{50}$ The dissent, objecting strenuously to resort to such general equitable principles, found no provision of the Federal Rules that

45. Montgomery, Chapter XI of the Bankmuptcy Act (Address before American Bar Association, September 9, 1940).

46. Securities and Exchange Commission v. United States Realty and Improvement Co., 60 Sup. Ct. 1044 (1940).

47. The petitioner was a large corporation with security issues widely held by the public, eight hundred and ninety-nine individual investors held share certificates representing the corporation's contingent liability on a guarantee of another corporation's bonds and 900,000 shares of its stock were outstanding, listed, and traded in on the New York Stock Exchange. Also, the public held sizable quantities of the debentures of the company.

48. In re United States Realty and Improvement Co., ro8 F. (2d) 794 (C. C. A. 2d, 1940) (Clark, J., dissenting), 88 U. of PA. L. REv. 873, 53 HARv. L. Rev. 1056, 49 YALE L. J. 927.

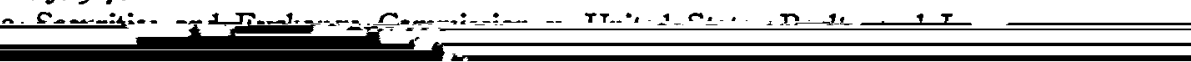


the Act have complicated, and not simplified, administration; and whether the result is an improvement is seriously open to question.

\section{Achievement of Objectives}

As previously mentioned, there are ten major objectives of the Chandler Act. Of present concern are the following:

I. To increase efficiency in administration.

2. To improve the procedural sections of the Act.

3. To minimize evasions by bankrupts.

4. To perfect the sections relative to preferences, liens and fraudlent conveyances, and the title of the trustee.

5. To make more effective the discharge provisions of the Act. ${ }^{114}$

In other words, the Chandler Act aims to secure larger dividends to creditors and to eliminate so far as possible the dishonest bankrupt. It is a deplorable fact that under the Act of 1898 the average dividend in bankruptcy proceedings was extremely low. For example, during I926-27 general creditors realized only 10.I I $\%$ on their unsecured liabilities in involuntary cases and $6.48 \%$ for voluntary and involuntary cases combined. ${ }^{115}$ Let us examine briefly what has been attempted in order to improve his situation.

Procedure has been streamlined. More rapid action means more economical action. The powers of a referee have been expanded so that he becomes virtually a judge, thus reducing the constant shuttling of small matters back and forth between the referee and judge. ${ }^{116}$ The summary jurisdiction of the bankruptcy court has been increased in vital spots. ${ }^{117}$ Government claims, as well as those of private creditors, must now be presented within six months after the date set for the first meeting of creditors. ${ }^{118}$ It was a demonstrated fact that under the Act of 1898 great delay and confusion were caused because government claims were not within the six-month rule. ${ }^{119}$ These and other procedural reforms should be definite time savers.

Incidentally, former Attorney General Murphy appointed a Committee on Bankruptcy Administration in April, 1939. One of the func-

II4. See supra p. Ir. H. R. REp. No. 1409, 75th Cong., 3d Sess. (1938) 3. Concurred in by SEN. REP. No. 1916, 75th Cong., 3d Sess. (1938) 3, 4. I Collier, BankRUPTCY (I4th ed. I940) 22.

II5. REP. ATT'Y GEN. (1927) I78. See Billig, note 5 supra at $4 \mathrm{I} 7$.

II6. §38. Moore's BankRUPTCY MANUAL (I939) II7; WeINStein, op. cit. supra note 7 at 79 .

II7. \$\$2 (2I), 60 (b), 67 (a) (4), 70 (a) (8). WEINSTeIN, op. cit. supra note 7 at $16,143,158$.

II8. \&57(n). HANNA AND MclaughLIN, op. cit. supra note 9 at 54 ; MOORE's BankRUptcy Manual (1939) 148; Weinstern, op. cit. supra note 7 at iro.

II9. WeINSTEIN, op. cit. supra note 7 at IIo. 
tions of this Committee is to study the fee system. From it has evolved a bill designed to place referees on a permanent salary basis upon the theory that the fee system now employed is inefficient and expensive $^{\mathbf{1 2 0}}$ It seems also that the Committee is in favor of eliminating creditor control and of proposing the appointment of permanent administrative officers, such as licensed, registered and official receivers, trustees, examiners and liquidators. ${ }^{121}$ Thus far these proposals have not been carried into effect. Although their purpose is to increase efficiency and economy in bankruptcy administration, their desirability has already given rise to divergence of opinion. ${ }^{122}$

Most important are the new and improved devices for detecting and checking the dishonest bankrupt. The new Section 7 requires the bankrupt to file a statement of his affairs within five days prior to the first meeting of the creditors. ${ }^{123}$ According to the Official Forms, this statement is designed to furnish the trustee, the creditors and the court with detailed information concerning the debtor's transactions by which concealment and fraud may be more easily discovered. ${ }^{124}$ The value of this new device is still a matter of speculation. It is, at any rate, a step in the right direction, and if properly carried out should have substantial utility. ${ }^{125}$ The bankrupt is now held to closer accountability concerning the purchase and disposal of assets. ${ }^{128}$ Provisions for examination of the bankrupt have likewise been materially strengthened. ${ }^{127}$

Detection of concealment of fraud means recovery of additional assets for creditors as well as the denial of a discharge. Some of the things that have been done to clarify and give teeth to the provisions of the Act.relative to fraudulent conveyances and preferences have already been mentioned. ${ }^{128}$ In addition, the trustee's title to assets of the bankrupt has been expanded. It is common practice for a man to secure extended credit on the strength of a prospective inheritance.

I20. Senate Bill 2550 (1939).

I21. Address of Jacob I. Weinstein to American Bar Association Convention (September II, I940), loc. cit. supra note I4.

122. "While I recognize that the Chandler Act, which has been in operation for only about two years, may not have cured all the defects and abuses of bankruptcy administration, nevertheless, it is still my conviction that in respect to the proposal of Attorney General Murphy, the fee system for referees, under the present set-up of the office, is the most feasible and workable method of compensating referees and that official administration of bankruptcy estates is not desirable or necessary." Ibid.

I23. \$7 (a) (8). See MoORE's BankRuptcy ManUal (1939); Weinstern, op. cit. supra note 7 at 32 .

124. Comprehensive requirements for information from the bankrupt are set forth in Official Form No. 2.

125. I Collier, BANKRUPTCY (I4th ed. I940) 995; Wolfe, Detection of Fraud under the New Bankruptcy Law (1938) I3 TEMP. L. Q. I, 6.

126. Wolfe, note I25 supra, at 7-9.

127. I COLIIER, BANKRUPTCY. (I4th ed. I940) 2 x.or et seq.; id. at 3 et seq.

128. See supra pp. $22,26$. 
Under the Act of 1898 the trustee succeeded to the debtor's title to assets as of the date of bankruptcy. ${ }^{128}$ Anything acquired thereafter by the bankrupt was free and clear of the claims of creditors in the bankruptcy court. ${ }^{130}$ Consequently such debtors developed the racket of using bankruptcy to defeat their creditors, receiving their inheritances subsequently, to the exclusion of their creditors. That racket has been at least partially squelched by the new Section $70^{131}$ wherein it is provided that property acquired by inheritance, bequest or devise within six months after bankruptcy shall none-the-less pass to the trustee. ${ }^{182}$

Discharge features of the Act have also been noticeably tightened. Adjudication now operates as an application for a discharge as to bankrupts other than corporations. ${ }^{133}$ Under the Act of 1898 bankrupts frequently delayed making application or secured continuances in the hope of lulling to sleep creditors who might otherwise file objections to the granting of a discharge. ${ }^{134}$ The trustee may now of his own volition file objections to a discharge, ${ }^{135}$ whereas under the Act of 1898 , he could act only with the consent of the creditors. ${ }^{136}$ Clari-

129. "The trustee of the estate of a bankrupt, upon his appointment and qualification, and his successor or successors, if he shall have one or more, upon his or their appointment and qualification shall in turn be vested by operation of law with the title of the bankrupt, as of the date he was adjudged a bankrupt, except in so far as it is to property which is exempt. . " $\$ 700$. Bankruptcy Act of I898, 30 STAT. 544 (1898), II U. S. C. A. \& IIO (I934).

I30. In re Baker, I3 F. (2d) 707 (C. C. A. 6th, I926), (1927) 27 Coc. I. Rev. 87, 36 YALE L. J. 272.

I3r. "These provisions seek to remedy situations which, under the old Act, had given rise to frequent and serious abuses and inequities." WeINSTEIN, op. cit. sipra note 7 at 157 .

132. Section 70 (a) (7) provides that the trustee shall be vested by operation of law with title to all "contingent remainders, executory devises and limitations, rights of entry for condition broken, rights or possibilities of reverter, and like interests in real property, which were non-assignable prior to bankruptcy and which, within six months thereafter, became assignable interests or estates or give rise to powers in the bankrupt to acquire assignable interests or estates; and . . . (8) all property which vests in the bankrupt within six months after bankruptcy by bequest, devise, or inheritance shall vest in the trustee and his successor and successors, if any, upon his or their appointment and qualification, as of the date when it vested in the bankrupt, and shall be free and discharged from any transfer made or suffered by the bankrupt after bankruptcy. All property in which the bankrupt has at the date of bankruptcy, an estate or interest by the entirety, and which within six months after bankruptcy becomes transferable in whole or in part solely by the bankrupt, shall, to the extent it becomes transferable, vest in the trustee and his successor and successors, if any, upon his or their appointment and qualification, as of the date of bankruptcy. . . ."

See WEINSTEIN, op. cit. supra note 7 , at I58: "If, within six months after bankruptcy, the contingency or event occurs so that any such right or interest becomes assignable by the bankrupt, or gives rise to a power in him to acquire an assignable interest or estate, then such right, interest or estate passes to the trustee, upon the happening of such contingency or event."

I33. § I4 (a) ; I Collier, BANkRUPTCY (14th ed. 1940) I256.

I34. Matter of Farrow, 28 F. Supp. 9 (S. D. Cal. 1939) ; I Collier, BankRuptcy (14th ed. 1940) 1256.

I35. § I4 (b) ; I Collier, BANKRUPTCY (I4th ed. I940) 1266, n. 3.

I36. Bankruptcy Act of 1898 , 30 STAT. 550 (1898), II U. S. C. A. 106 (1934) \$ I4 (b) ; I COLLIER, BANKRUPTCY (I4th ed. I940) I266, n. 3. 
fication of the criminal provisions of the Act, as well as those relating to grounds for objecting to discharges, are calculated to make more difficult the obtaining of a discharge by the dishonest bankrupt. ${ }^{137}$ The bankruptcy court may now request the United States Attorney to investigate the affairs of a bankrupt and to oppose his discharge if probable grounds for so doing are discovered. ${ }^{138}$ Whether or not this provision will prove efficacious is open to doubt. Its success depends upon the extent to which it is utilized. In at least one instance it has already been the means of discovering a very large sum of concealed assets. ${ }^{139}$

These are but a few of the many innovations in the Act which are designed to improve the efficiency of bankruptcy administration, to provide increased dividends for creditors, and to reduce dishonesty to a minimum. It is, as yet, too early to determine the extent to which they will be successful. At best they will probably be no more than partial aids, for in at least two respects they fail to strike at fundamental questions. The defects and evils of bankruptcy administration have existed for years not entirely because of a faulty statute but partially because of characteristic lack of interest displayed by creditors. ${ }^{140}$ When dividends are prevalently small, the ordinary business man is prompted to write off a debt as a loss when the debtor becomes bankrupt, or to turn over his claim to agencies which in turn dominate bankruptcy proceedings. ${ }^{141}$ The draftsmen of the Chandler Act have made some efforts to stimulate creditor-participation. They have recognized the at 70 .

137. §29; MOORE's BankRUPtcy ManUal 1I0; WeINStein, op. cit. supra note 7,

I38. § I4 (d) ; I CoIrier, BANKRUPTCX (I4th ed. I940) I269, n. 4, I385.

I39. In the federal court, Eastern District of Pennsylvania, one Mr. Schireson was convicted on a criminal charge and the case is now pending on appeal.

140. "The breakdown in practice of the theory that the creditors can be relied on to control and intelligently manage administration is strikingly shown by the abuses surrounding the machinery of electing the trustee.

"This machinery is as follows: After the adjudication of the bankrupt the referee sends out notices to the creditors of a first meeting, at which the bankrupt may be examined and the trustee elected. The referee does not send out proofs of claim with these notices.

"Blank proofs of claim are sent through the mail by claim solicitors or trade associations or, frequently, attorneys. Accompanying these proofs of claim are letters stating that if the proof of claim is returned, the sender will take care of filing it, of collecting the dividend and remitting the proceeds to the particular creditor. Usually, in the body of the proof of claim, embedded in technical verbiage, is a proxy authorizing the sender to vote the creditor's claim at all meetings and to collect the creditors' dividends.

"Creditors who receive these communications, glad to be relieved of the nuisance of obtaining the necessary form, sign the proof of claim, often ignorant of the fact that a stranger has been thereby authorized to vote for the election of a trustee. Creditors rarely attend meetings, with the result that since Section 56 of the Act permits a majority in number and amount of those present or represented to control, it generally happens that a handful of proxies will be sufficient to control the election of a trustee." Donovan, Report ON THE AdMinistration OF BANKRUpt Estates (1930) I3, I4.

I4I. Ibid. See In re Scott, 53 F. (2d) 89 (W. D. Mich. 193I); cf. Rinderknecht v. Toledo Ass'n of Credit Men, I3 F. Supp. 555 (N. D. Ohio I935). 
right of creditor' committees to appear and be heard. ${ }^{142}$ They have attempted to curb the control of bankruptcy proceedings by credit agencies for their own selfish ends. ${ }^{143}$ This domination by credit agencies is in itself a very controversial question. It is sometimes for the good, but too frequently for the bad. It is undemocratic and expensive, resulting in reducing ultimate dividends to creditors. Its very existence, however, is made possible by the inertia of creditors. On the other hand, it is the recognized practice of some agencies to take only the hopeless cases into bankruptcy. When there is hope, more economical out-of-court adjustments are utilized. ${ }^{144}$

It is doubtful whether the Chandler Act has done enough to stimulate creditor-participation. Yet it is difficult to discover what more could be done. The vicious circle must somehow be broken. Creditors refuse to participate because the smallness of dividends makes participation unprofitable. Yet non-participation is in itself undoubtedly a cause of reduced dividends. It makes possible the control of proceedings by selfish interests. If the reforms of the Chandler Act succeed in increasing dividends, there is hope for a break in the circle which will end the apathy of creditors and stimulate their interest. To be sure, the appointment of permanent, licensed trustees with virtually complete control over proceedings might well result in increased effciency, greater economy of administration, and correspondingly larger dividends. ${ }^{145}$ But such a step would be the end of creditor-control. There is a feeling that the creditors among whom the pot is to be divided should have a voice as to how that should be done. A theory of trustee-control sounds so undemocratic that serious objections to its adoption would undoubtedly be voiced. ${ }^{146}$

The lack of interest of creditors in turn breeds another of the fundamental evils which the Chandler Act has probably failed to curb. It is a sad commentary upon our judicial system that the practice of bankruptcy law is not in the best of repute. In metropolitan centers too much of it is concentrated in a very small group of attorneys. Too many of them have no sincere interest in proper administration-bank-

I42. $\$ 57$ (d).

143. "Claims of $\$ 50$ or less shall not be counted in computing the number of creditors voting or present at creditors' meetings, but shall be counted in computing the amount." \$56 (c).

"This is a new provision. It is intended to overcome the domination of a proceeding by collection agencies and self-serving coalitions. By coralling and combining a preponderating or controlling number of the smaller claims, these groups were frequently enabled to run a proceeding and defeat the wishes of the fewer but substantial creditors." WEINSTEIN, op. cit. supra note 7 at ro6.

I44. Mulder and Solomon, note 29 supra, n. I.

I45. Supra p. 33.

I46. Supra p. 33. 
ruptcy is too frequently utilized as a racket for collecting attorney's fees. On the other hand, the opinion has been expressed that conditions are improving under the Chandler Act, that the practice of bankruptcy law is acquiring a cloak of respectability. ${ }^{147}$ Such is undoubtedly true as to the rehabilitation features of the Act, and its expansion to all fields of bankruptcy is greatly to be desired.

\section{Conciusion}

The defects of the Chandler Act which have been mentioned, as well as others, are by no means fatal. Eventually they will be corrected by sensible courts and by amendment. The Act itself is indeed a work of art. The scientific effort which went into its formation, the same attitude which is characterizing its administration, are worthy of a happy fate. It is fortunate that there has as yet been no concerted drive for change; instead there seems to be general willingness not to tamper until experience justifies alteration. The reforms have been accepted with good grace; there is no disposition to emasculate. ${ }^{148}$

Bankruptcy today is more important than it has ever been. It must therefore be administered with constant awareness of the lofty objectives of the Chandler Act. There will always be evils. There will always be the great mass of no-asset cases, of debtors who are beyond rehabilitation. But administration can be efficient, dividends can be increased, and bankruptcy need not be forever a haven for the dishonest. The Act has gone far in that direction. The rest depends upon sympathetic and sensible courts, upon a vigilant Congress, upon the ethics of the practicing lawyers, and upon a continuation of the scientific attitude.

I47. Layton, Practical Workings of the Chandler Act (Address before the American Bar Association Section on Commercial Law, September 10, 1940).

I48. This seemed to be the general feeling manifested at the Bankruptcy Symposium of the American Bar Association Convention on September II, I940. 
ruptcy is too frequently utilized as a racket for collecting attorney's fees. On the other hand, the opinion has been expressed that conditions are improving under the Chandler Act, that the practice of bankruptcy law is acquiring a cloak of respectability. ${ }^{147}$ Such is undoubtedly true as to the rehabilitation features of the Act, and its expansion to all fields of bankruptcy is greatly to be desired.

\section{Conciusion}

The defects of the Chandler Act which have been mentioned, as well as others, are by no means fatal. Eventually they will be corrected by sensible courts and by amendment. The Act itself is indeed a work of art. The scientific effort which went into its formation, the same attitude which is characterizing its administration, are worthy of a happy fate. It is fortunate that there has as yet been no concerted drive for change; instead there seems to be general willingness not to tamper until experience justifies alteration. The reforms have been accepted with good grace; there is no disposition to emasculate. ${ }^{148}$

Bankruptcy today is more important than it has ever been. It must therefore be administered with constant awareness of the lofty objectives of the Chandler Act. There will always be evils. There will always be the great mass of no-asset cases, of debtors who are beyond rehabilitation. But administration can be efficient, dividends can be increased, and bankruptcy need not be forever a haven for the dishonest. The Act has gone far in that direction. The rest depends upon sympathetic and sensible courts, upon a vigilant Congress, upon the ethics of the practicing lawyers, and upon a continuation of the scientific attitude.

I47. Layton, Practical Workings of the Chandler Act (Address before the American Bar Association Section on Commercial Law, September 10, 1940).

I48. This seemed to be the general feeling manifested at the Bankruptcy Symposium of the American Bar Association Convention on September II, I940. 
ruptcy is too frequently utilized as a racket for collecting attorney's fees. On the other hand, the opinion has been expressed that conditions are improving under the Chandler Act, that the practice of bankruptcy law is acquiring a cloak of respectability. ${ }^{147}$ Such is undoubtedly true as to the rehabilitation features of the Act, and its expansion to all fields of bankruptcy is greatly to be desired.

\section{Conciusion}

The defects of the Chandler Act which have been mentioned, as well as others, are by no means fatal. Eventually they will be corrected by sensible courts and by amendment. The Act itself is indeed a work of art. The scientific effort which went into its formation, the same attitude which is characterizing its administration, are worthy of a happy fate. It is fortunate that there has as yet been no concerted drive for change; instead there seems to be general willingness not to tamper until experience justifies alteration. The reforms have been accepted with good grace; there is no disposition to emasculate. ${ }^{148}$

Bankruptcy today is more important than it has ever been. It must therefore be administered with constant awareness of the lofty objectives of the Chandler Act. There will always be evils. There will always be the great mass of no-asset cases, of debtors who are beyond rehabilitation. But administration can be efficient, dividends can be increased, and bankruptcy need not be forever a haven for the dishonest. The Act has gone far in that direction. The rest depends upon sympathetic and sensible courts, upon a vigilant Congress, upon the ethics of the practicing lawyers, and upon a continuation of the scientific attitude.

I47. Layton, Practical Workings of the Chandler Act (Address before the American Bar Association Section on Commercial Law, September 10, 1940).

I48. This seemed to be the general feeling manifested at the Bankruptcy Symposium of the American Bar Association Convention on September II, I940. 
ruptcy is too frequently utilized as a racket for collecting attorney's fees. On the other hand, the opinion has been expressed that conditions are improving under the Chandler Act, that the practice of bankruptcy law is acquiring a cloak of respectability. ${ }^{147}$ Such is undoubtedly true as to the rehabilitation features of the Act, and its expansion to all fields of bankruptcy is greatly to be desired.

\section{Conciusion}

The defects of the Chandler Act which have been mentioned, as well as others, are by no means fatal. Eventually they will be corrected by sensible courts and by amendment. The Act itself is indeed a work of art. The scientific effort which went into its formation, the same attitude which is characterizing its administration, are worthy of a happy fate. It is fortunate that there has as yet been no concerted drive for change; instead there seems to be general willingness not to tamper until experience justifies alteration. The reforms have been accepted with good grace; there is no disposition to emasculate. ${ }^{148}$

Bankruptcy today is more important than it has ever been. It must therefore be administered with constant awareness of the lofty objectives of the Chandler Act. There will always be evils. There will always be the great mass of no-asset cases, of debtors who are beyond rehabilitation. But administration can be efficient, dividends can be increased, and bankruptcy need not be forever a haven for the dishonest. The Act has gone far in that direction. The rest depends upon sympathetic and sensible courts, upon a vigilant Congress, upon the ethics of the practicing lawyers, and upon a continuation of the scientific attitude.

I47. Layton, Practical Workings of the Chandler Act (Address before the American Bar Association Section on Commercial Law, September 10, 1940).

I48. This seemed to be the general feeling manifested at the Bankruptcy Symposium of the American Bar Association Convention on September II, I940. 
ruptcy is too frequently utilized as a racket for collecting attorney's fees. On the other hand, the opinion has been expressed that conditions are improving under the Chandler Act, that the practice of bankruptcy law is acquiring a cloak of respectability. ${ }^{147}$ Such is undoubtedly true as to the rehabilitation features of the Act, and its expansion to all fields of bankruptcy is greatly to be desired.

\section{Conciusion}

The defects of the Chandler Act which have been mentioned, as well as others, are by no means fatal. Eventually they will be corrected by sensible courts and by amendment. The Act itself is indeed a work of art. The scientific effort which went into its formation, the same attitude which is characterizing its administration, are worthy of a happy fate. It is fortunate that there has as yet been no concerted drive for change; instead there seems to be general willingness not to tamper until experience justifies alteration. The reforms have been accepted with good grace; there is no disposition to emasculate. ${ }^{148}$

Bankruptcy today is more important than it has ever been. It must therefore be administered with constant awareness of the lofty objectives of the Chandler Act. There will always be evils. There will always be the great mass of no-asset cases, of debtors who are beyond rehabilitation. But administration can be efficient, dividends can be increased, and bankruptcy need not be forever a haven for the dishonest. The Act has gone far in that direction. The rest depends upon sympathetic and sensible courts, upon a vigilant Congress, upon the ethics of the practicing lawyers, and upon a continuation of the scientific attitude.

I47. Layton, Practical Workings of the Chandler Act (Address before the American Bar Association Section on Commercial Law, September 10, 1940).

I48. This seemed to be the general feeling manifested at the Bankruptcy Symposium of the American Bar Association Convention on September II, I940. 
ruptcy is too frequently utilized as a racket for collecting attorney's fees. On the other hand, the opinion has been expressed that conditions are improving under the Chandler Act, that the practice of bankruptcy law is acquiring a cloak of respectability. ${ }^{147}$ Such is undoubtedly true as to the rehabilitation features of the Act, and its expansion to all fields of bankruptcy is greatly to be desired.

\section{Conciusion}

The defects of the Chandler Act which have been mentioned, as well as others, are by no means fatal. Eventually they will be corrected by sensible courts and by amendment. The Act itself is indeed a work of art. The scientific effort which went into its formation, the same attitude which is characterizing its administration, are worthy of a happy fate. It is fortunate that there has as yet been no concerted drive for change; instead there seems to be general willingness not to tamper until experience justifies alteration. The reforms have been accepted with good grace; there is no disposition to emasculate. ${ }^{148}$

Bankruptcy today is more important than it has ever been. It must therefore be administered with constant awareness of the lofty objectives of the Chandler Act. There will always be evils. There will always be the great mass of no-asset cases, of debtors who are beyond rehabilitation. But administration can be efficient, dividends can be increased, and bankruptcy need not be forever a haven for the dishonest. The Act has gone far in that direction. The rest depends upon sympathetic and sensible courts, upon a vigilant Congress, upon the ethics of the practicing lawyers, and upon a continuation of the scientific attitude.

I47. Layton, Practical Workings of the Chandler Act (Address before the American Bar Association Section on Commercial Law, September 10, 1940).

I48. This seemed to be the general feeling manifested at the Bankruptcy Symposium of the American Bar Association Convention on September II, I940. 
ruptcy is too frequently utilized as a racket for collecting attorney's fees. On the other hand, the opinion has been expressed that conditions are improving under the Chandler Act, that the practice of bankruptcy law is acquiring a cloak of respectability. ${ }^{147}$ Such is undoubtedly true as to the rehabilitation features of the Act, and its expansion to all fields of bankruptcy is greatly to be desired.

\section{Conciusion}

The defects of the Chandler Act which have been mentioned, as well as others, are by no means fatal. Eventually they will be corrected by sensible courts and by amendment. The Act itself is indeed a work of art. The scientific effort which went into its formation, the same attitude which is characterizing its administration, are worthy of a happy fate. It is fortunate that there has as yet been no concerted drive for change; instead there seems to be general willingness not to tamper until experience justifies alteration. The reforms have been accepted with good grace; there is no disposition to emasculate. ${ }^{148}$

Bankruptcy today is more important than it has ever been. It must therefore be administered with constant awareness of the lofty objectives of the Chandler Act. There will always be evils. There will always be the great mass of no-asset cases, of debtors who are beyond rehabilitation. But administration can be efficient, dividends can be increased, and bankruptcy need not be forever a haven for the dishonest. The Act has gone far in that direction. The rest depends upon sympathetic and sensible courts, upon a vigilant Congress, upon the ethics of the practicing lawyers, and upon a continuation of the scientific attitude.

I47. Layton, Practical Workings of the Chandler Act (Address before the American Bar Association Section on Commercial Law, September 10, 1940).

I48. This seemed to be the general feeling manifested at the Bankruptcy Symposium of the American Bar Association Convention on September II, I940. 
ruptcy is too frequently utilized as a racket for collecting attorney's fees. On the other hand, the opinion has been expressed that conditions are improving under the Chandler Act, that the practice of bankruptcy law is acquiring a cloak of respectability. ${ }^{147}$ Such is undoubtedly true as to the rehabilitation features of the Act, and its expansion to all fields of bankruptcy is greatly to be desired.

\section{Conciusion}

The defects of the Chandler Act which have been mentioned, as well as others, are by no means fatal. Eventually they will be corrected by sensible courts and by amendment. The Act itself is indeed a work of art. The scientific effort which went into its formation, the same attitude which is characterizing its administration, are worthy of a happy fate. It is fortunate that there has as yet been no concerted drive for change; instead there seems to be general willingness not to tamper until experience justifies alteration. The reforms have been accepted with good grace; there is no disposition to emasculate. ${ }^{148}$

Bankruptcy today is more important than it has ever been. It must therefore be administered with constant awareness of the lofty objectives of the Chandler Act. There will always be evils. There will always be the great mass of no-asset cases, of debtors who are beyond rehabilitation. But administration can be efficient, dividends can be increased, and bankruptcy need not be forever a haven for the dishonest. The Act has gone far in that direction. The rest depends upon sympathetic and sensible courts, upon a vigilant Congress, upon the ethics of the practicing lawyers, and upon a continuation of the scientific attitude.

I47. Layton, Practical Workings of the Chandler Act (Address before the American Bar Association Section on Commercial Law, September 10, 1940).

I48. This seemed to be the general feeling manifested at the Bankruptcy Symposium of the American Bar Association Convention on September II, I940. 
ruptcy is too frequently utilized as a racket for collecting attorney's fees. On the other hand, the opinion has been expressed that conditions are improving under the Chandler Act, that the practice of bankruptcy law is acquiring a cloak of respectability. ${ }^{147}$ Such is undoubtedly true as to the rehabilitation features of the Act, and its expansion to all fields of bankruptcy is greatly to be desired.

\section{Conciusion}

The defects of the Chandler Act which have been mentioned, as well as others, are by no means fatal. Eventually they will be corrected by sensible courts and by amendment. The Act itself is indeed a work of art. The scientific effort which went into its formation, the same attitude which is characterizing its administration, are worthy of a happy fate. It is fortunate that there has as yet been no concerted drive for change; instead there seems to be general willingness not to tamper until experience justifies alteration. The reforms have been accepted with good grace; there is no disposition to emasculate. ${ }^{148}$

Bankruptcy today is more important than it has ever been. It must therefore be administered with constant awareness of the lofty objectives of the Chandler Act. There will always be evils. There will always be the great mass of no-asset cases, of debtors who are beyond rehabilitation. But administration can be efficient, dividends can be increased, and bankruptcy need not be forever a haven for the dishonest. The Act has gone far in that direction. The rest depends upon sympathetic and sensible courts, upon a vigilant Congress, upon the ethics of the practicing lawyers, and upon a continuation of the scientific attitude.

I47. Layton, Practical Workings of the Chandler Act (Address before the American Bar Association Section on Commercial Law, September 10, 1940).

I48. This seemed to be the general feeling manifested at the Bankruptcy Symposium of the American Bar Association Convention on September II, I940. 
ruptcy is too frequently utilized as a racket for collecting attorney's fees. On the other hand, the opinion has been expressed that conditions are improving under the Chandler Act, that the practice of bankruptcy law is acquiring a cloak of respectability. ${ }^{147}$ Such is undoubtedly true as to the rehabilitation features of the Act, and its expansion to all fields of bankruptcy is greatly to be desired.

\section{Conciusion}

The defects of the Chandler Act which have been mentioned, as well as others, are by no means fatal. Eventually they will be corrected by sensible courts and by amendment. The Act itself is indeed a work of art. The scientific effort which went into its formation, the same attitude which is characterizing its administration, are worthy of a happy fate. It is fortunate that there has as yet been no concerted drive for change; instead there seems to be general willingness not to tamper until experience justifies alteration. The reforms have been accepted with good grace; there is no disposition to emasculate. ${ }^{148}$

Bankruptcy today is more important than it has ever been. It must therefore be administered with constant awareness of the lofty objectives of the Chandler Act. There will always be evils. There will always be the great mass of no-asset cases, of debtors who are beyond rehabilitation. But administration can be efficient, dividends can be increased, and bankruptcy need not be forever a haven for the dishonest. The Act has gone far in that direction. The rest depends upon sympathetic and sensible courts, upon a vigilant Congress, upon the ethics of the practicing lawyers, and upon a continuation of the scientific attitude.

I47. Layton, Practical Workings of the Chandler Act (Address before the American Bar Association Section on Commercial Law, September 10, 1940).

I48. This seemed to be the general feeling manifested at the Bankruptcy Symposium of the American Bar Association Convention on September II, I940. 
ruptcy is too frequently utilized as a racket for collecting attorney's fees. On the other hand, the opinion has been expressed that conditions are improving under the Chandler Act, that the practice of bankruptcy law is acquiring a cloak of respectability. ${ }^{147}$ Such is undoubtedly true as to the rehabilitation features of the Act, and its expansion to all fields of bankruptcy is greatly to be desired.

\section{Conciusion}

The defects of the Chandler Act which have been mentioned, as well as others, are by no means fatal. Eventually they will be corrected by sensible courts and by amendment. The Act itself is indeed a work of art. The scientific effort which went into its formation, the same attitude which is characterizing its administration, are worthy of a happy fate. It is fortunate that there has as yet been no concerted drive for change; instead there seems to be general willingness not to tamper until experience justifies alteration. The reforms have been accepted with good grace; there is no disposition to emasculate. ${ }^{148}$

Bankruptcy today is more important than it has ever been. It must therefore be administered with constant awareness of the lofty objectives of the Chandler Act. There will always be evils. There will always be the great mass of no-asset cases, of debtors who are beyond rehabilitation. But administration can be efficient, dividends can be increased, and bankruptcy need not be forever a haven for the dishonest. The Act has gone far in that direction. The rest depends upon sympathetic and sensible courts, upon a vigilant Congress, upon the ethics of the practicing lawyers, and upon a continuation of the scientific attitude.

I47. Layton, Practical Workings of the Chandler Act (Address before the American Bar Association Section on Commercial Law, September 10, 1940).

I48. This seemed to be the general feeling manifested at the Bankruptcy Symposium of the American Bar Association Convention on September II, I940. 
ruptcy is too frequently utilized as a racket for collecting attorney's fees. On the other hand, the opinion has been expressed that conditions are improving under the Chandler Act, that the practice of bankruptcy law is acquiring a cloak of respectability. ${ }^{147}$ Such is undoubtedly true as to the rehabilitation features of the Act, and its expansion to all fields of bankruptcy is greatly to be desired.

\section{Conciusion}

The defects of the Chandler Act which have been mentioned, as well as others, are by no means fatal. Eventually they will be corrected by sensible courts and by amendment. The Act itself is indeed a work of art. The scientific effort which went into its formation, the same attitude which is characterizing its administration, are worthy of a happy fate. It is fortunate that there has as yet been no concerted drive for change; instead there seems to be general willingness not to tamper until experience justifies alteration. The reforms have been accepted with good grace; there is no disposition to emasculate. ${ }^{148}$

Bankruptcy today is more important than it has ever been. It must therefore be administered with constant awareness of the lofty objectives of the Chandler Act. There will always be evils. There will always be the great mass of no-asset cases, of debtors who are beyond rehabilitation. But administration can be efficient, dividends can be increased, and bankruptcy need not be forever a haven for the dishonest. The Act has gone far in that direction. The rest depends upon sympathetic and sensible courts, upon a vigilant Congress, upon the ethics of the practicing lawyers, and upon a continuation of the scientific attitude.

I47. Layton, Practical Workings of the Chandler Act (Address before the American Bar Association Section on Commercial Law, September 10, 1940).

I48. This seemed to be the general feeling manifested at the Bankruptcy Symposium of the American Bar Association Convention on September II, I940. 
ruptcy is too frequently utilized as a racket for collecting attorney's fees. On the other hand, the opinion has been expressed that conditions are improving under the Chandler Act, that the practice of bankruptcy law is acquiring a cloak of respectability. ${ }^{147}$ Such is undoubtedly true as to the rehabilitation features of the Act, and its expansion to all fields of bankruptcy is greatly to be desired.

\section{Conciusion}

The defects of the Chandler Act which have been mentioned, as well as others, are by no means fatal. Eventually they will be corrected by sensible courts and by amendment. The Act itself is indeed a work of art. The scientific effort which went into its formation, the same attitude which is characterizing its administration, are worthy of a happy fate. It is fortunate that there has as yet been no concerted drive for change; instead there seems to be general willingness not to tamper until experience justifies alteration. The reforms have been accepted with good grace; there is no disposition to emasculate. ${ }^{148}$

Bankruptcy today is more important than it has ever been. It must therefore be administered with constant awareness of the lofty objectives of the Chandler Act. There will always be evils. There will always be the great mass of no-asset cases, of debtors who are beyond rehabilitation. But administration can be efficient, dividends can be increased, and bankruptcy need not be forever a haven for the dishonest. The Act has gone far in that direction. The rest depends upon sympathetic and sensible courts, upon a vigilant Congress, upon the ethics of the practicing lawyers, and upon a continuation of the scientific attitude.

I47. Layton, Practical Workings of the Chandler Act (Address before the American Bar Association Section on Commercial Law, September 10, 1940).

I48. This seemed to be the general feeling manifested at the Bankruptcy Symposium of the American Bar Association Convention on September II, I940. 
ruptcy is too frequently utilized as a racket for collecting attorney's fees. On the other hand, the opinion has been expressed that conditions are improving under the Chandler Act, that the practice of bankruptcy law is acquiring a cloak of respectability. ${ }^{147}$ Such is undoubtedly true as to the rehabilitation features of the Act, and its expansion to all fields of bankruptcy is greatly to be desired.

\section{Conciusion}

The defects of the Chandler Act which have been mentioned, as well as others, are by no means fatal. Eventually they will be corrected by sensible courts and by amendment. The Act itself is indeed a work of art. The scientific effort which went into its formation, the same attitude which is characterizing its administration, are worthy of a happy fate. It is fortunate that there has as yet been no concerted drive for change; instead there seems to be general willingness not to tamper until experience justifies alteration. The reforms have been accepted with good grace; there is no disposition to emasculate. ${ }^{148}$

Bankruptcy today is more important than it has ever been. It must therefore be administered with constant awareness of the lofty objectives of the Chandler Act. There will always be evils. There will always be the great mass of no-asset cases, of debtors who are beyond rehabilitation. But administration can be efficient, dividends can be increased, and bankruptcy need not be forever a haven for the dishonest. The Act has gone far in that direction. The rest depends upon sympathetic and sensible courts, upon a vigilant Congress, upon the ethics of the practicing lawyers, and upon a continuation of the scientific attitude.

I47. Layton, Practical Workings of the Chandler Act (Address before the American Bar Association Section on Commercial Law, September 10, 1940).

I48. This seemed to be the general feeling manifested at the Bankruptcy Symposium of the American Bar Association Convention on September II, I940. 
ruptcy is too frequently utilized as a racket for collecting attorney's fees. On the other hand, the opinion has been expressed that conditions are improving under the Chandler Act, that the practice of bankruptcy law is acquiring a cloak of respectability. ${ }^{147}$ Such is undoubtedly true as to the rehabilitation features of the Act, and its expansion to all fields of bankruptcy is greatly to be desired.

\section{Conciusion}

The defects of the Chandler Act which have been mentioned, as well as others, are by no means fatal. Eventually they will be corrected by sensible courts and by amendment. The Act itself is indeed a work of art. The scientific effort which went into its formation, the same attitude which is characterizing its administration, are worthy of a happy fate. It is fortunate that there has as yet been no concerted drive for change; instead there seems to be general willingness not to tamper until experience justifies alteration. The reforms have been accepted with good grace; there is no disposition to emasculate. ${ }^{148}$

Bankruptcy today is more important than it has ever been. It must therefore be administered with constant awareness of the lofty objectives of the Chandler Act. There will always be evils. There will always be the great mass of no-asset cases, of debtors who are beyond rehabilitation. But administration can be efficient, dividends can be increased, and bankruptcy need not be forever a haven for the dishonest. The Act has gone far in that direction. The rest depends upon sympathetic and sensible courts, upon a vigilant Congress, upon the ethics of the practicing lawyers, and upon a continuation of the scientific attitude.

I47. Layton, Practical Workings of the Chandler Act (Address before the American Bar Association Section on Commercial Law, September 10, 1940).

I48. This seemed to be the general feeling manifested at the Bankruptcy Symposium of the American Bar Association Convention on September II, I940. 